\title{
PRORAČUN NOSIVOSTI I STABILNOSTI UMERENO VITKIH I VITKIH CENTRIČNO PRITISNUTIH KRUŽNIH CFT STUBOVA
}

\section{CALCULATION OF LOAD CAPACITY AND STABILITY OF MODERATELY SLENDER AND SLENDER AXIAL LOADED CIRCULAR CFT COLUMNS}

\author{
Marija LAZOVIĆ \\ Biljana DERETIĆ-STOJANOVIĆ \\ Janko RADOVANOVIĆ
}

\section{UVOD}

Stubovi od kružnih šupljih čeličnih profila ispunjenih betonom, u daljem tekstu CFT stubovi (eng. Concrete Filled Tubes), zbog svojih konstruktivnih prednosti, našli su široku primenu u savremenoj inženjerskoj praksi. Proračun nosivosti i stabilnosti CFT stubova zasniva se na proračunu prema graničnim stanjima. Određivanje granične nosivosti CFT stubova složeno je zbog nelinearnih karakteristika betona i čelika, imperfekcije vezane za geometriju i oblik nosača, zaostalih napona u čeličnom profilu, istorije opterećenja, ekscentričnosti opterećenja, uticaja drugog reda $\mathrm{i}$ tako dalje. Kod umereno vitkih i vitkih CFT stubova, gubitak nosivosti zasniva se na problemu stabilnosti. $U$ tom slučaju moraju se uzeti u obzir uticaji drugog reda. Tačnost rešenja, pre svega, zavisi od izbora nelinearnog konstitutivnog modela za materijal, kao i od načina definisanja graničnih uslova oslanjanja CFT stuba. U radu je prikazan program sopstvenog eksperimentalnog ispitivanja nosivosti i stabilnosti umereno vitkih i vitkih CFT kružnih stubova određenih geometrijskih i materijalnih karakteristika. Primenom računarskog programa ABAQUS detaljno je prikazano numeričko modeliranje nosivosti CFT kružnih stubova, pri čemu je uzeta u obzir

Marija Lazović, mast. inž. građ.

Građevinski fakultet Univerziteta u Beogradu, Bulevar kralja

Aleksandra 73, 11000 Beograd, i-mejl:

mlazovic@grf.bg.ac.rs

Prof. dr Biljana Deretić-Stojanović, dipl. inž. građ.

Građevinski fakultet Univerziteta u Beogradu, Bulevar kralja

Aleksandra 73, 11000 Beograd, i-mejl: biljads@eunet.rs

Janko Radovanović, mast.inž.građ.

„Morava" v.d.o.o., Ljubićka 8, Čačak

i-mejl: jankoradovanovic87@gmail.com

\author{
ORIGINALNI NAUČNI RAD \\ ORIGINAL SCIENTIFIC PAPER \\ UDK: 624.012 .45 .046 \\ doi:10.5937/GRMK1802057L
}

\section{INTRODUCTION}

Columns from circular concrete filled steel tube, in the further CFT columns (Concrete Filled Tubes), have been widely used in modern engineering practice due to their constructive advantages. Calculation of the load and stability of CFT columns is based on the boundary states. Determination of the limit load capacity of CFT columns is complex due to non-linear characteristics of concrete and steel, imperfection related to geometry and shape of the column, residual stresses in the steel tube, load history, load eccentricity, second order influence, and others. In moderately slender and slender CFT columns, load capacity loss is based on a stability problem. In that case, the second-order effects must be taken into calculation. The accuracy of the results depends primarily on the choice of a nonlinear constitutive model for the material, as well as on the method of defining the boundary conditions at the ends of the CFT column. The paper presents a program of our own experimental testing of the load capacity and stability of moderately slender and slender CFT circular columns of certain geometric and material characteristics. Using the ABAQUS computer program, the numerical modelling of the CFT circular column load capacity is presented in

\footnotetext{
Marija Lazovic, MSc. civ. eng.

Faculty of Civil Engineering, University of Belgrade Bulevar kralja Aleksandra 73, 11000 Belgrade e-mail: mlazovic@grf.bg.ac.rs

Biljana Deretic Stojanovic, PhD, civ. eng.

Faculty of Civil Engineering, University of Belgrade

Bulevar kralja Aleksandra 73, 11000 Belgrade

e-mail: biljads@eunet.rs

Janko Radovanovic, MSc. civ. eng.

V.d.o.o. "Morava" Ljubicka 8, 32102 Cacak

e-mail: jankoradovanovic87@gmail.com
} 
geometrijska i materijalna nelinearnost. Dobijeni rezultati sopstvenih eksperimentalnih ispitivanja za različite odnose $\mathrm{D} / \mathrm{t}$ i različite granične uslove oslanjanja, upoređeni su s važećim pravilnicima, kao i s rezultatima primenom računarskog programa ABAQUS.

\section{PREGLED PRETHODNIH ISTRAŽIVANJA}

$\mathrm{U}$ literaturi se mogu pronaći radovi mnogih autora koji su se bavili analizom nosivosti spregnutih CFT stubova, kako teorijski, tako i eksperimentalno [1, 2, 3, 4, $5,6,7,8,9]$

Primenom važećih pravilnika: EC4 (Eurocode 4) [10], $\mathrm{ACl}$ (American Concrete Institute) [11], AS (Australian Standard) [12], AISC (American Institute of Steel Construction) [13], može se sa odgovarajućom tačnošću sračunati nosivost poprečnog preseka spregnutog stuba, uzimajući u obzir klasu betona i kvalitet čelika.

Pri proračunu nosivosti CFT stubova prema graničnim stanjima, na tačnost rešenja značajan uticaj ima definisanje veze između napona i dilatacije za beton i čelik. U literaturi se može pronaći čitav niz predloga ovih veza koji s manjom ili većom tačnošću opisuju ponašanje betona i čelika $[3,14,15,16,17,18,19,20]$.

Dužina CFT stuba ima značajan uticaj na njegovu nosivost [21, 22, 23, 24]. Kod kratkih i umereno vitkih stubova do gubitka nosivosti može doći usled loma po betonu ili usled plastifikacije čeličnog profila. Međutim, gubitak nosivosti vitkih stubova zasniva se na problemu stabilnosti. Kod vitkih stubova, lom nastaje usled izvijanja u elastičnoj oblasti, dok kod umereno vitkih stubova do izvijanja dolazi u plastičnoj oblasti. U tom slučaju, za umereno vitke stubove, u proračunu je potrebno koristiti tangentne module elastičnosti koji zahtevaju dobro poznavanje veze napon-dilatacija.

Primenom računarskog programa ABAQUS [25] uspešno se mogu modelirati nelinearni konstitutivni modeli za beton, čelik, kao i veze betonske ispune i čeličnog profila.

\section{EKSPERIMENTALNO ISPITIVANJE NOSIVOSTI I STABILNOSTI CFT STUBOVA}

$\mathrm{U}$ radu je prikazano eksperimentalno ispitivanje nosivosti i stabilnosti CFT umereno vitkih i vitkih stubova koji su s gornje strane zglobno oslonjeni, a s donje zglobno oslonjeni ili uklješteni. Eksperimentalna ispitivanja umereno vitkih i vitkih CFT stubova rađena su na postojećem objektu GP „NAPRED" koji se rekonstruiše i nadziđuje. Ispitana je stabilnost četiri uzorka dužine $\mathrm{L}=4.00 \mathrm{~m}$ označena sa $C 1, C 2, C 3$ i C4. Uzorci C1 i C2 spregnuti su CFT stubovi koji su s donje strane uklješteni u čeličnu ploču dimenzija $450 \mathrm{~mm} \cdot 450 \mathrm{~mm} \cdot 30 \mathrm{~mm}$. S gornje strane, uzorcima je sprečeno horizontalno pomeranje, a dozvoljeni su rotacija i vertikalno pomeranje, što odgovara pokretnom osloncu. Uzorci C3 i C4 spregnuti su CFT stubovi koji su i s donje i s gornje strane zglavkasto oslonjeni.

Odnos spoljašnjeg prečnika i debljine zida čeličnog profila za uzorke C1, C2, C3 i C4 iznosi: $\mathrm{D} / \mathrm{t}=101.6$ $\mathrm{mm} / 2.7 \mathrm{~mm}, \mathrm{D} / \mathrm{t}=114.3 \mathrm{~mm} / 2.7 \mathrm{~mm}, \mathrm{D} / \mathrm{t}=101.6 \mathrm{~mm} / 4.0$ details, taking into account the geometric and material nonlinearity. The results from experimental researches for various $D / t$ ratio and different boundary conditions were compared with current regulations, as well as with the results of using the computer program ABAQUS.

\section{REVIEW OF PREVIOUS RESEARCH}

In the literature, the works of a large number of authors dealing with the analysis of the load of composite CFT columns can be found, both theoretically and experimentally [1, 2, 3, 4, 5, 6, 7, 8, 9]

Using the current regulations: EC4 (Eurocode 4) [10], $\mathrm{ACl}$ (American Concrete Institute) [11], AS (Australian Standard) [12], AISC [13], calculations of load capacity of the cross section of the composite column can be made, with the correct regulations, considering the class of concrete and the steel class. In calculating the load capacity of the CFT columns according to the boundary conditions, the connection between the stress and the strain for concrete and steel makes a significant influence on defining the accuracy of the solution. In the literature, a whole series of proposals for these connections can be found which describe the behaviour of concrete and steel with more or less accuracy [3, 14, $15,16,17,18,19,20]$. The length of the CFT column has a significant impact on its load capacity $[21,22,23$, 24]. In the case of short and moderately slender column, the load loss can occur due to fracture of the concrete or due to the yield strength of steel tubes. However, the loss of load capacity of slender columns is based on the problem of stability. In slender columns, the fracture is caused by the buckling in the elastic area, while in moderately slender columns, the buckling happens in the plastic area. In this case, for moderately slender columns, the tangent modules of elasticity need to be used in the calculation, which requires a good knowledge of the stress-strain relation. By using the ABAQUS computer program [25], nonlinear constitutive models for concrete, steel, as well as connection between concrete core and steel profiles can be modelled successfully.

\section{EXPERIMENTAL TESTING OF LOAD CAPACITY AND STABILITY OF CFT COLUMNS}

The paper presents an experimental study of the load capacity and stability of CFT moderately slender and slender columns, which are free support from the upper side, and free support or fixed on the bottom. Experimental tests of moderately slender and slender CFT columns were performed on the existing "NAPRED" facility that is being reconstructed. The stability of four samples of length $L=4.00 \mathrm{~m}$ was tested, marked with $C 1, C 2, C 3$ and $C 4$. The samples $C 1$ and C2 are composite CFT columns that are fixed on the bottom to the steel plate dimensions $450 \mathrm{~mm} \cdot 450 \mathrm{~mm} \cdot 30 \mathrm{~mm}$. On the upper side, the horizontal movement are prevented from the samples, and rotation and vertical movement are permitted, which corresponds to the movable support. Samples C3 and C4 are composite CFT columns, which are also free support from the lower and upper sides.

The ratio of the outer diameter and wall thickness of 
$\mathrm{mm}, \mathrm{D} / \mathrm{t}=114.3 \mathrm{~mm} / 4.0 \mathrm{~mm}$, respektivno. Čelik je kvaliteta S355. Beton koji ispunjava čelični profil je klase C25/30, pri čemu srednja vrednost ispitane čvrstoće betona na pritisak na cilindru dimenzija $150 \mathrm{~mm} \cdot 300 \mathrm{~mm}$ iznosi $\mathrm{f}_{\mathrm{c}}{ }^{\prime}=26.70 \mathrm{MPa}$.

$\mathrm{Za}$ potrebe izvođenja ispitivanja konstruisana je specijalna garnitura. Ona se sastoji od spoljašnjeg nepokretnog čeličnog rama dimenzija 2300 mm.900 mm.900 mm s dve hidraulične prese prečnika $\varnothing 200$ mm, kao i unutrašnjeg pokretnog čeličnog rama dimenzija $2400 \mathrm{~mm} \cdot 600 \mathrm{~mm} \cdot 600 \mathrm{~mm}$. Spoljašnji čelični ram predstavlja balast, dok se unutrašnjim čeličnim ramom na uzorak nanosi sila pritiska. Hod presa je $40 \mathrm{~cm}$. Hidraulične prese pokreću se pomoću dva elektromotora (snage $7 \mathrm{~kW}$ i 10k W) s dve hidraulične pumpe (za niži i viši pritisak). Kapacitet presa je 300 bari, što znači da je moguće ostvariti silu intenziteta od oko 1885 kN. Na kraju svakog radnog hoda hidraulične prese meri se pritisak na manometru i on se unosi u radnu tabelu. Zavisnost između pritiska prikazanog na manometru i sile jeste linearna. Da bi moglo da se nanese relativno veliko opterećenje, potrebno je da postoje uslovi za formiranje kontratereta suprotno silama pritiska. Kao kontrateret koristi se betonski blok dimenzija $300 \mathrm{~cm} \cdot 300$ $\mathrm{cm} \cdot 100 \mathrm{~cm}$, pri čemu se sila zatezanja na betonski blok prenosi preko osam visokovrednih ankera $\varnothing 25 \mathrm{~mm}$ dužine $\mathrm{L}=25 \mathrm{~cm}$ koji su zavareni za rebrastu armaturu $\varnothing 25 \mathrm{~mm}$ i ubetonirani u betonski blok (sl.1). the steel tube for the samples $C 1, C 2, C 3$ and $C 4$ is: $\mathrm{D} / \mathrm{t}=101.6 \mathrm{~mm} / 2.7 \mathrm{~mm}, \mathrm{D} / \mathrm{t}=114.3 \mathrm{~mm} / 2.7 \mathrm{~mm}$, $\mathrm{D} / \mathrm{t}=101.6 \mathrm{~mm} / 4.0 \mathrm{~mm}, \quad \mathrm{D} / \mathrm{t}=114.3 \mathrm{~mm} / 4.0 \mathrm{~mm}$ respectively. Steel class is S355. Concrete that fills the steel tube is class $C 25 / 30$, where the middle value of the tested strength of concrete on the cylinder of dimensions $150 \mathrm{~mm} \cdot 300 \mathrm{~mm}$ is $\mathrm{f}_{\mathrm{c}}{ }^{\prime}=26.70 \mathrm{MPa}$. For the needs of the test, a special set was constructed. The set consists of an outer immobile steel frame with dimensions 2300 $\mathrm{mm} \cdot 900 \mathrm{~mm} \cdot 900 \mathrm{~mm}$ with two hydraulic presses (diameter $\varnothing 200 \mathrm{~mm}$ ), as well as the internal movable steel frame with dimensions $2400 \mathrm{~mm} \cdot 600 \mathrm{~mm} \cdot 600 \mathrm{~mm}$. The outer steel frame is ballast, while the internal steel frame is used to apply pressure force on the sample. The stroke length is $40 \mathrm{~cm}$. Hydraulic presses are powered by two electric motors (power $7 \mathrm{~kW}$ and 10kW) with two hydraulic pumps (for lower and higher pressure). The capacity of the press is 300 bars, which means it is possible to achieve a force of intensity of about $1885 \mathrm{kN}$. At the end of each working stroke of the hydraulic presses the pressure is measured on the pressure gauge and it is entered into the work chart. The relation between the pressure shown on the gauge and the force is linear. In order to be able to apply a relatively high load, it is necessary that there are conditions for counterweight formation against the pressure forces. A concrete block of dimensions $300 \mathrm{~cm} \cdot 300 \mathrm{~cm} \cdot 100 \mathrm{~cm}$ is used as a counter load, whereby the tensile force on the concrete block is transmitted through eight high-value anchors $\varnothing 25 \mathrm{~mm}$ length $\mathrm{L}=25 \mathrm{~cm}$ which are welded to the ribbed reinforcement $\varnothing 25 \mathrm{~mm}$ and embedded in the concrete block (Fig.1).

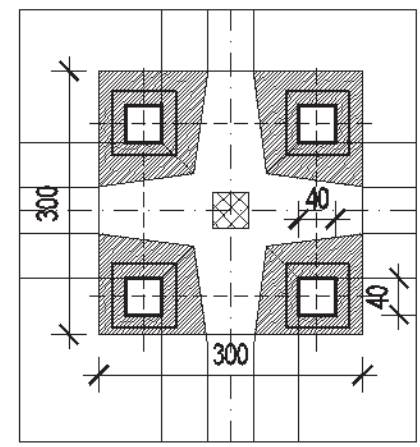

Slika 1: Osnova betonskog bloka

Figure 1: The base of the concrete block

Beton je spravljen u fabrici GP „NAPRED• a.d., dok je betoniranje rađeno u objektu GP „NAPRED• a.d. uz nabijanje betona metalnom šipkom u nekoliko slojeva. Kontrolni uzorci betonirani su u čeličnim kalupima oblika cilindra dimenzija 150 mm.300 mm [26]. Usvojena je srednja vrednost čvrstoće betona na pritisak koja iznosi $\mathrm{f}_{\mathrm{c}}{ }^{\prime}=26.70 \mathrm{MPa}$.

Kako bi se ostvarilo centrično unošenje opterećenja, primenjen je specijalni uređaj-kalota. Opterećenje za svaki ispitani uzorak naneto je u inkrementima od po 5 bara, što odgovara sili od 31.42 kN. Nanošenje opterećenja do loma trajalo je oko tri minuta za svaki ispitani uzorak, pa se može smatrati da je opterećenje kratkotrajno. Kako bi se opterećenje nanelo istovremeno
Concreting was made out at the factory "NAPRED", while the concrete works were done in the "NAPRED" building pouring concrete with metal rod in several layers. Control samples are concreted in steel moulds of a cylinder dimension $150 \mathrm{~mm} \cdot 300 \mathrm{~mm}$ [26]. The middle value of the strength of the concrete on the pressure $\mathrm{f}_{\mathrm{c}}{ }^{\prime}=26.70 \mathrm{MPa}$ was adopted. A special device-calotte was applied in order to achieve centric loading of the load. The load for each sample tested was in increments of 5 bar, corresponding to the force of $31.42 \mathrm{kN}$. Applying the load to fracture took about 3 minutes for each sample tested, so the load can be considered to be short-lived. In order to apply the load simultaneously to the steel tube and the concrete core, during the 
na čelični profil i betonsko jezgro, prilikom betoniranja stuba izbetonirano je nekoliko centimetara betonskog jezgra više od dužine čeličnog profila. Zatim su na dan ispitivanja brusilicom za beton fino poravnate gornja i donja površina stuba. Na slici 2 prikazana je garnitura za ispitivanje uzoraka s hidrauličnim presama. concreting of the column, core was made to be several centimetres longer than the length of the steel tube. Then, on the day of testing with the grinder for concrete, the upper and lower surfaces of the column are finely aligned. Figure 2 shows a set for testing samples with hydraulic presses.

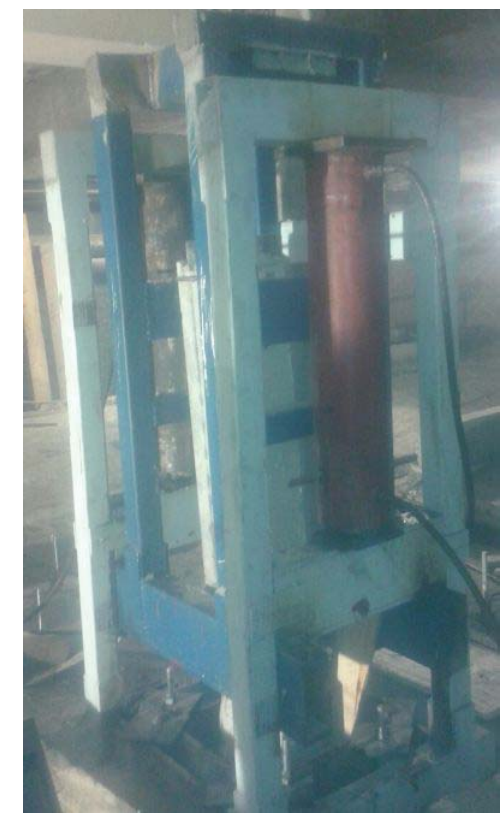

Slika 2: Garnitura za ispitivanje uzoraka s hidrauličnim presama

Figure 2: Set for sample testing with hydraulic presses

Pomoću dozne i ugibomera, postavljenih na vrhu stuba, kontinualno su izmereni sila i vertikalno pomeranje, odnosno skraćenje stuba. Pomoću ugibomera postavljenih na $0.35 \cdot \mathrm{L}$ od gornjeg kraja stuba za uzorke C1 i C2, odnosno na $0.50 \cdot \mathrm{L}$ od gornjeg kraja stuba za uzorke C3 i C4 meri se horizontalno pomeranje. Za sve ispitane uzorke ostvarena je tačnost $\pm 01 \mathrm{kN}$ za silu i $0.01 \mathrm{~mm}$ za vertikalno i horizontalno pomeranje. Na slici 3 prikazan je položaj postavljenih ugibomera.
With the help of the force transducer and displacement transducer placed at the top of the column, the force and vertical movement, or shortening of the columns, are continuously measured. Using displacement transducer placed on $0.35 \cdot \mathrm{L}$ from the upper end of the samples $C 1$ and $C 2$, and $0.50 \cdot \mathrm{L}$ from the upper end of the samples $C 3$ and $C 4$ the horizontal movement was measured. For all tested samples an accuracy of $\pm 01 \mathrm{kN}$ for force and $0.01 \mathrm{~mm}$ for vertical and horizontal movement was achieved. Figure 3 shows the position of displacement transducers.

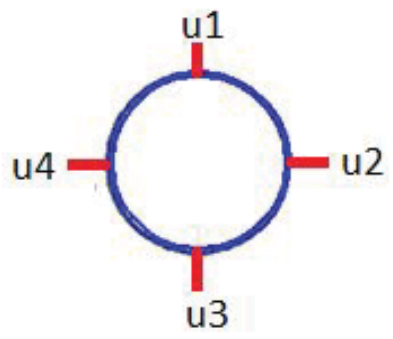

Slika 3: Položaj postavljenih ugibomera

Figure 3: Position of the setups of the displacement transducer 


\section{PRIKAZ I OBRADA REZULTATA} EKSPERIMENTALNIH ISPITIVANJA

Dimenzije poprečnog preseka uzoraka $C 1, C 2, C 3$ i C4 dužine $\mathrm{L}=4.00 \mathrm{~m}$, kao i karakteristike materijala ispitanih uzoraka, prethodno su opisane u pogavlju 3. $\mathrm{Na}$ slici 4 prikazan je dijagram zavisnosti kritične sile izvijanja od inženjerske dilatacije $\varepsilon=\Delta \mathrm{L} / \mathrm{L}$ za uzorak $C 1$. Gubitak stabilnosti CFT stuba ostvaren je pri sili od $327.7 \mathrm{kN}$, dok je izmereno maksimalno horizontalno pomeranje na $0.35 \cdot \mathrm{L}$ od gornjeg kraja stuba $41.24 \mathrm{~mm}$.

\section{EXAMINATION AND PROCESSING OF EXPERIMENTAL EXAMINATION RESULTS}

The dimensions of the cross sections of the samples are $C 1, C 2, C 3$ and $C 4$ lengths $L=4.00 \mathrm{~m}$, as well as the characteristics of the materials of the tested samples were previously described in Chapter 3. In Figure 4, a diagram of the dependence of the buckling force on the engineering strain $\varepsilon=\Delta \mathrm{L} / \mathrm{L}$ is shown for the sample $C 1$. The loss of stability of the CFT column is realized at a force of $327.7 \mathrm{kN}$, while the measured maximum horizontal displacement on $0.35 \cdot \mathrm{L}$ from upper side of the column was $41.24 \mathrm{~mm}$.

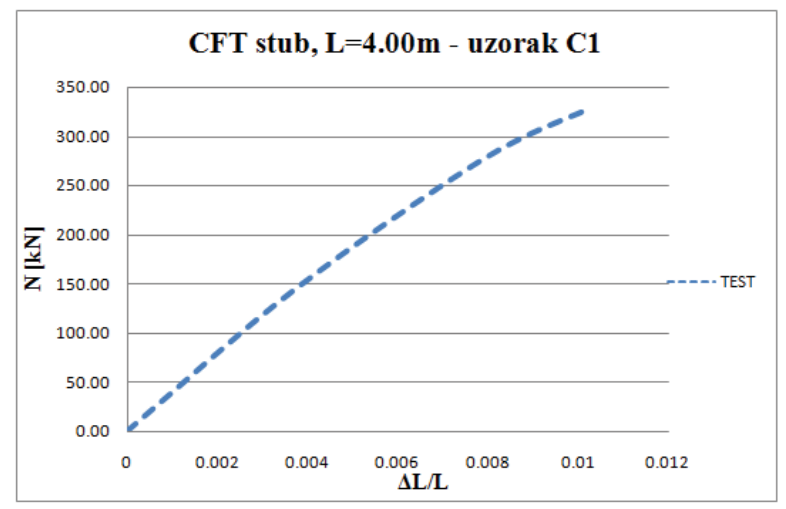

Slika 4: Dijagram $P_{c r}-\Delta L / L$ za uzorak $C 1$

Figure 4: Diagram $P_{c r}-\Delta L / L$ for sample $C 1$

Na slici 5 prikazan je dijagram zavisnosti kritične sile izvijanja od inženjerske dilatacije za uzorak C2. Gubitak stabilnosti CFT stuba ostvaren je pri sili od $489.1 \mathrm{kN}$, dok izmereno maksimalno horizontalno pomeranje na 0.35.L od gornjeg kraja stuba iznosi $43.27 \mathrm{~mm}$.
The Figure 5 shows a diagram of the dependence of the buckling force on the engineering strain is shown for the sample C2. The loss of stability of the CFT column is realized at a force of $489.1 \mathrm{kN}$, while the measured maximum horizontal displacement on $0.35 \cdot \mathrm{L}$ from upper side of the column was $43.27 \mathrm{~mm}$.

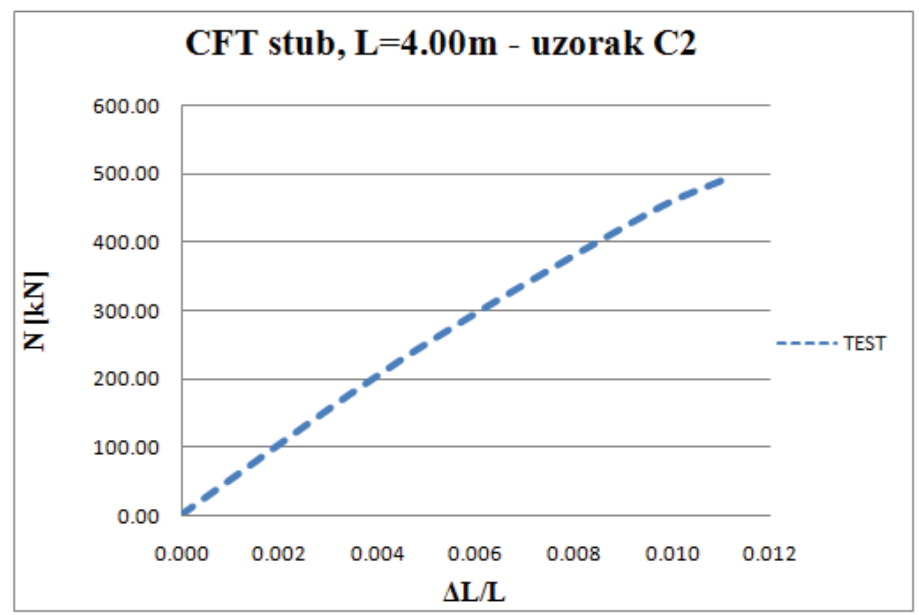

Slika 5: Dijagram $P_{c r}-\Delta L / L$ za uzorak $C 2$

Figure 5: Diagram $P_{c r}-\Delta L / L$ for sample $C 2$

Na osnovu oblika dijagrama može se zaključiti da je ponašanje uzoraka $C 1$ i $C 2$ približno elastično. Međutim,
Based on the shape of the diagram, it can be concluded that the behaviour of the samples $C 1$ and $C 2$ 
nastala je i plastifikacija određenog dela preseka.

Na slici 6 prikazan je dijagram zavisnosti kritične sile izvijanja od inženjerske dilatacije za uzorak C3. Gubitak stabilnosti CFT stuba ostvaren je pri sili od $226.0 \mathrm{kN}$, dok izmereno maksimalno horizontalno pomeranje na 0.5· L od gornjeg kraja stuba iznosi $32.93 \mathrm{~mm}$. is approximately elastic. However, the yield strength of steel tubes of a certain part of the cross section has occurred. The Figure 6 shows a diagram of the dependence of the buckling force on the engineering strain shown for the sample C3. The loss of stability of the CFT column is realized at a force of $226.0 \mathrm{kN}$, while the measured maximum horizontal displacement on $0.5 \cdot \mathrm{L}$ from upper side of the column was $32.93 \mathrm{~mm}$.

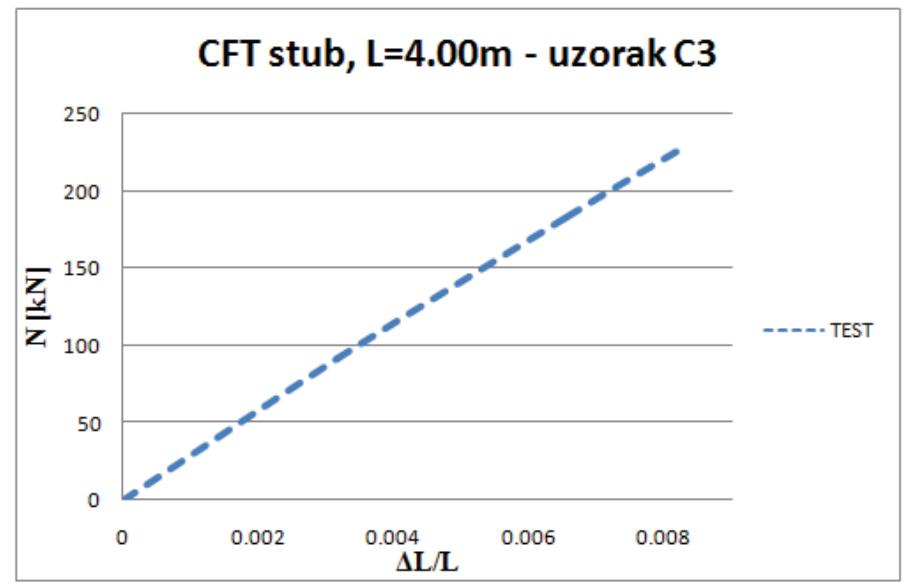

Slika 6: Dijagram $P_{c r}-\Delta L / L$ za uzorak C3

Figure 6: Diagram $P_{c r}-\Delta L / L$ for sample $C 3$

Na slici 7 prikazan je dijagram zavisnosti kritične sile izvijanja od inženjerske dilatacije za uzorak C4. Gubitak stabilnosti CFT stuba ostvaren je pri sili od $319.0 \mathrm{kN}$, dok izmereno maksimalno horizontalno pomeranje stuba na $0.5 \cdot \mathrm{L}$ od gornjeg kraja stuba iznosi $36.45 \mathrm{~mm}$.
The Figure 7 shows a diagram of the dependence of the buckling force on the engineering strain shown for the sample C4. The loss of stability of the CFT column is realized at a force of $319.0 \mathrm{kN}$, while the measured maximum horizontal displacement on $0.5 \cdot \mathrm{L}$ from upper side of the column was $36.45 \mathrm{~mm}$.

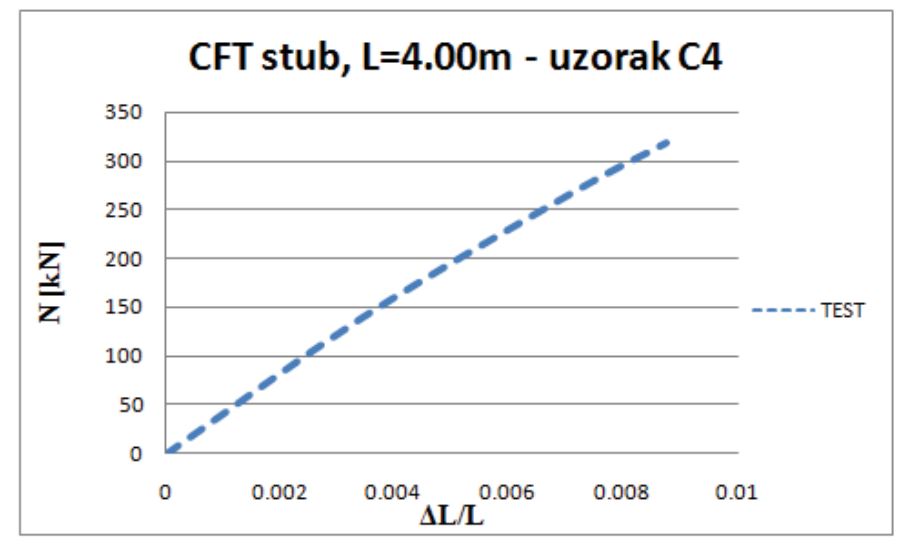

Slika 7: Dijagram $P_{c r}-\Delta L / L$ za uzorak C4

Figure 7: Diagram $P_{c r}-\Delta L / L$ for sample C4

$\mathrm{Na}$ osnovu oblika dijagrama može se zaključiti da je ponašanje uzoraka C3 i C4 elastično, odnosno da je gubitak stabilnosti ovih CFT stubova nastao u elastičnoj oblasti. Elastično ponašanje uzoraka C3 i C4 moglo se i očekivati, s obzirom na to što je reč o vitkim stubovima.
Based on the shape of the diagram, it can be concluded that the behaviour of samples C3 and C4 is elastic, the loss of stability of these CFT columns has occurred in an elastic region. The elastic behaviour of the $C 3$ and $C 4$ samples could be expected, since these are slender columns. 


\section{NUMERIČKO MODELIRANJE I SIMULACIJE}

Za modeliranje betonskog jezgra primenjeni su C3D8R konačni elementi (8-node linear brick, reduced integration with hourglass control), za modeliranje čeličnog profila usvojeni su S4R konačni elementi (4node general-purpose shell, reduced integration with hourglass control, finite membrane strains), dok je veza čeličnog šupljeg profila s betonskim jezgrom modelirana pomoću surface to surface contact elemenata. Budući da je reč o umereno vitkim i vitkim elementima, zanemaren je efekat utezanja $[10,15,17]$. U radu je primenjen Concrete Damaged Plasticity model [25], pri čemu je zadat ugao dilatacije od $20^{\circ}$. Usvojen Poissonov koeficijent iznosi 0.2. Za vezu napon-dilatacija za neutegnut beton usvojena je kriva prikazana na slici 8 , a koju su predložili autori Moon J. i ostali [3]. Dilatacija $\varepsilon_{c}$,' koja odgovara čvrstoći neutegnutog betona na pritisak $f_{c}{ }^{\prime}$ jeste 0.003 . Usvojeno je linearno ponašanje betona do vrednosti $0.5 \cdot f_{c}{ }^{\prime}$.

\section{NUMERICAL MODELLING AND SIMULATION}

For the modelling of the concrete core, C3D8R finite elements (8-node linear brick, reduced integration with hourglass control) were applied, for the modelling of the steel tube were adopted S4R finite elements (4-node general-purpose shell, reduced integration with hourglass control, finite membrane strains ), while the connection of the steel tube to the concrete core is modelled by surface to surface contact elements. Since it is a matter of moderately slender and slender columns, the confinement effect is ignored [10, 15, 17]. The Concrete Damaged Plasticity model [25] was applied in the paper, with an angle of dilatation of $20^{\circ}$. The adopted Poisson coefficient is 0.2 . For the connection stressstrain for non-confined concrete, the curve shown in Figure 8 was adopted, suggested by the authors of Moon J. and others [3]. Strain $\varepsilon_{c}$, that corresponds to the strength of non-confined concrete on the pressure $f_{c}{ }^{\prime}$ is 0.003 . Linear behaviour of concrete has been adopted until the value of $0.5 \cdot f_{c}^{\prime}$.

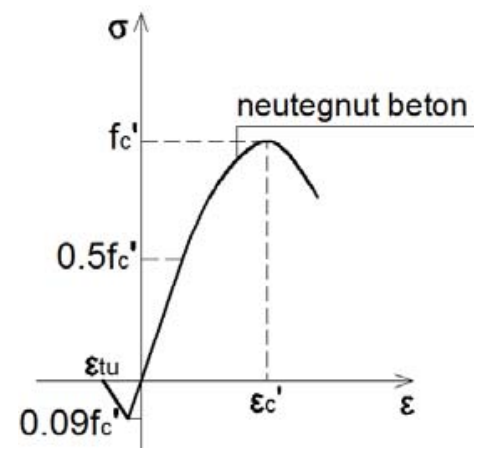

Slika 8: Dijagram $\sigma-\varepsilon$ za neutegnut betn

Figure 8: Diagram $\sigma-\varepsilon$ for non-confined concrete

Modul elastičnosti neutegnutog betona određuje se $u$ skladu sa EC2 [26] na osnovu sledećeg izraza:
The elasticity modulus of non-confined concrete is determined according to EC2 [26] based on the following formula:

$$
\mathrm{E}_{\mathrm{c}}=22000 \cdot\left[\frac{\mathrm{f}_{\mathrm{ck}}+8}{10}\right]^{0.3}[\mathrm{MPa}]
$$

Krivolinijski deo dijagrama $\sigma-\varepsilon$ na slici 7, koji se kreće od napona na granici proporcionalnosti 0.5 . $f_{c}{ }^{\prime}$ do napona $f_{c}{ }^{\prime}$, definisan je sledećim izrazom [18]:
The curvilinear part of the diagram $\sigma-\varepsilon$ in Figure 7, which ranges from the stress value at the proportionality limit $0.5 \cdot f_{c}{ }^{\prime}$ to stress value $0.5 \cdot f_{c}{ }^{\prime}$, is defined by the following formula [18]:

$$
\sigma=\frac{\mathrm{E}_{\mathrm{c}} \cdot \varepsilon_{\mathrm{c}}}{1+\left(\mathrm{R}+\mathrm{R}_{\mathrm{E}}-2\right) \cdot\left(\frac{\varepsilon}{\varepsilon_{c}^{\prime}}\right)-(2 \cdot R-1) \cdot\left(\frac{\varepsilon}{\varepsilon_{c}^{\prime}}\right)^{2}+R \cdot\left(\frac{\varepsilon}{\varepsilon_{c}^{\prime}}\right)^{3}}
$$

gde se koeficijenti $R_{E}$ i $R$ računaju prema sledećim izrazima: where the coefficients $R_{E}$ and $R$ are calculated according to the following expressions:

$$
\mathrm{R}_{\mathrm{E}}=\frac{E_{c} \cdot \varepsilon}{f_{c}^{\prime}}
$$




$$
\mathrm{R}=\frac{R_{E} \cdot\left(R_{\sigma}-1\right)}{\left(R_{\varepsilon}-1\right)^{2}}-\frac{1}{R_{\varepsilon}}
$$

dok su $R_{\sigma}$ i $R_{\varepsilon}$ jednaki 4 [46].

$\mathrm{Za}$ konstrukcioni čelik $\mathrm{u}$ radu je primenjen VonMises-ov model sa izotropnim ojačanjem. Na slici 9 prikazan je usvojen konstitutivni model za konstrukcioni čelik [3]. while $R_{\sigma}$ and $R_{c}$ are equal.

Von-Mises model with isotropic reinforcement was used for structural steel. Figure 9 shows the adopted constitutive model for structural steel [3].

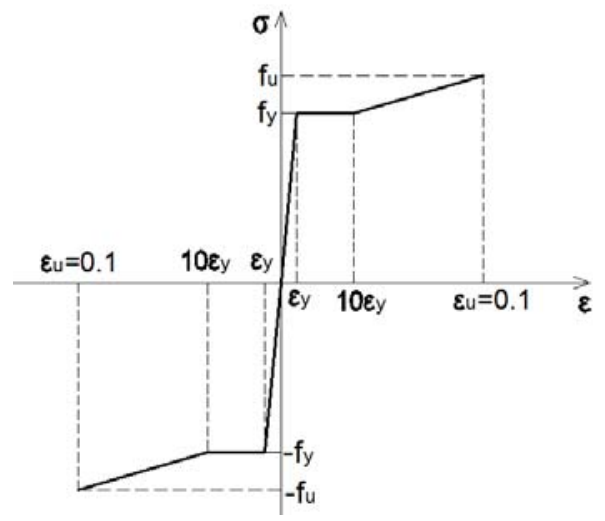

Slika 9: Dijagram $\sigma-\varepsilon$ za konstrukcioni čelik Figure 9: Diagram $\sigma-\varepsilon$ for structural steel

gde su: $f_{y}$ granica razvlačenja konstrukcionog čelika, $\varepsilon_{y}$ dilatacija koja odgovara granici razvlačenja, $f_{u}$ granica kidanja konstrukcionog čelika i $\varepsilon_{u}$ odgovarajuća dilatacija. Usvojen Young-ov modul elastičnosti konstrukcionog čelika iznosi $210 \mathrm{GPa}$, dok Poisson-ov koeficijent iznosi 0.3.

Veza čeličnog šupljeg profila s betonskim jezgrom može se modelirati pomoću surface to surface contact elemenata [25]. U radu su primenjeni kontakt-elementi koji definišu ponašanje veze $u$ upravnom i tangencijalnom pravcu.

Analiziran je uticaj odnosa D/t kao i uticaj graničnih uslova oslanjanja na vrednost kritične sile izvijanja $P_{c r}$. Opterećenje je naneto $u$ inkrementima primenom modifikovane Riks-ove metode dostupne u programu ABAQUS [25] koja se zasniva na Newton-Raphson-ovoj metodi.

- Uticaj odnosa D/t na stabilnost CFT stuba

Razmatrani su sledeći odnosi D/t: $101.6 \mathrm{~mm} / 2.7$ $\mathrm{mm}, 101.6 \mathrm{~mm} / 4.0 \mathrm{~mm}, 114.3 \mathrm{~mm} / 2.7 \mathrm{~mm}, 114.3$ $\mathrm{mm} / 4.0 \mathrm{~mm}$.

Klasa betona je C25/30, dok je kvalitet čelika S355. CFT stub uklješten je na donjem kraju, dok je na gornjem kraju zglavkasto oslonjen. Na slikama 10, 11 i 12 prikazani su rezultati proračuna za CFT stub odnosa $\mathrm{D} / \mathrm{t}=101.6 \mathrm{~mm} / 2.7 \mathrm{~mm}$ i to prikaz horizontalnog pomeranja u trenutku gubitka stabilnosti CFT stuba, prvi ton izvijanja i vrednost kritične sile izvijanja, respektivno. Maksimalna vrednost horizontalnog pomeranja $u$ trenutku gubitka stabilnosti CFT stuba iznosi $40.35 \mathrm{~mm}$. Tonovi izvijanja CFT stuba dobijeni su primenom Buckling analize. U sledećem modelu korišćeni su tonovi izvijanja kao oblik deformacije za proračun metodom RIKS, zadavanjem funkcije imperfekcije prema sledećoj formuli: where: $f_{y}$ is yield strength of steel, $\varepsilon_{y}$ is the yield strain of steel, $f_{u}$ is tensile strength of steel and $\varepsilon_{u}$ is the corresponding strain. The Young's modulus of elasticity of the structural steel is $210 \mathrm{GPa}$, while the Poisson coefficient is 0.3

The connection of the steel tube to the concrete core can be modelled using surface to surface contact elements [25]. In this work, contact elements are defined which define the behaviour of the connection in the perpendicular and tangential direction.

The influence of D/t ratio, as well as the influence of the boundary conditions on the value of the buckling force $P_{c r}$ is analyzed. The load was applied in increments using a modified Rix method available in ABAQUS [25] based on the Newton-Raphson method.

- Infuence D/t ratio on stability of the CFT column

The following D/t ratios were analyzed: 101.6 $\mathrm{mm} / 2.7 \mathrm{~mm}, 101.6 \mathrm{~mm} / 4.0 \mathrm{~mm}, 114.3 \mathrm{~mm} / 2.7 \mathrm{~mm}$, $114.3 \mathrm{~mm} / 4.0 \mathrm{~mm}$.

Concrete class is C25/30, while the steel class is S355. The CFT column is fixed at the lower end, while at the upper end it is free supported. Figures 10, 11 and 12 show the results of the calculation for the CFT column ratio $\mathrm{D} / \mathrm{t}=101.6 \mathrm{~mm} / 2.7 \mathrm{~mm}$ and this is a horizontal displacement at the moment of loss of stability of the CFT column, the first tone of the buckling and the value of the buckling force, respectively. The maximum horizontal displacement value at the moment of loss of stability of the CFT column is $40.35 \mathrm{~mm}$. The tones of the CFT columns were obtained using the Buckling analysis. In the following model, the tone is used as a form of deformation for the calculation by the RIKS method by setting the imperfection function according to the following formula: 


$$
\sum \mathrm{X}_{\mathrm{i}}=\sum_{i=1}^{M} w_{i} \cdot \phi_{i}
$$

pri čemu su: $w_{i}$-faktor skaliranja, $\phi_{i}$ - i-ti ton izvijanja. U modelu je uzet prvi ton kao dominantan ton izvijanja $s$ najmanjom silom izvijanja.
$W_{i}$-scaling factor, $c p-i$ tone of buckling. In the model, the first tone is taken as the dominant tone of the buckling with the lowest buckling force.

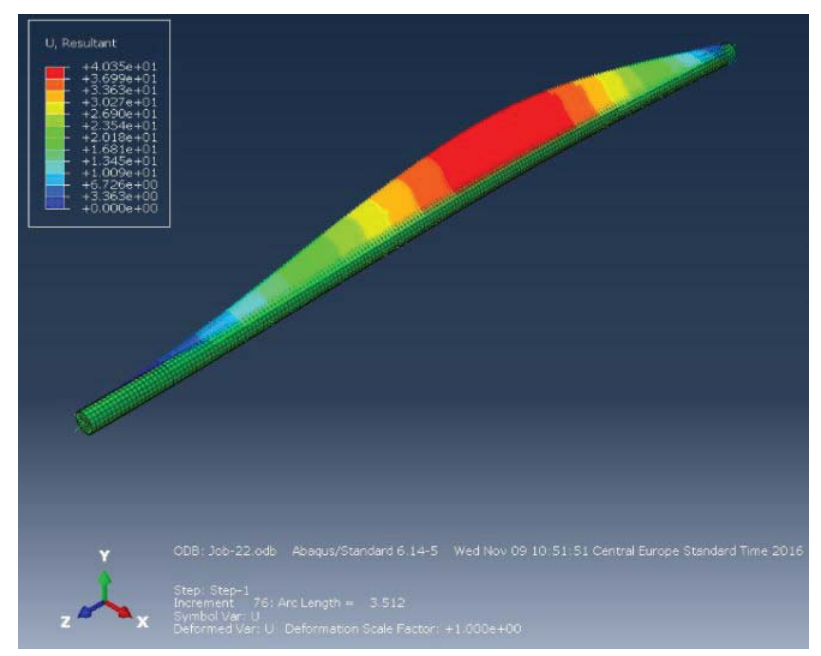

Slika 10: Rezultati proračuna za uzorak C1-prikaz horizontalnog pomeranja Figure 10: Results of the sample calculations C1-horizontal displacement

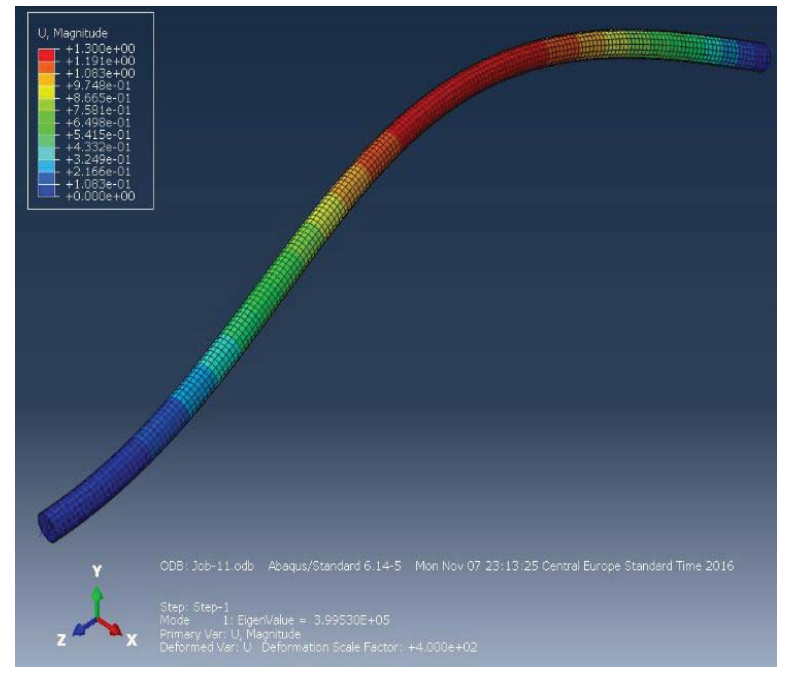

Slika 11: Rezultati proračuna za uzorak C1-prvi ton izvijanja Figure 11: Calculation Results for Sample C1 - first buckling tone

Faktor proporcionalnosti za prvi ton oscilovanja $\lambda$ primenjen je u Riks-ovoj metodi kako bi se dobila vrednost kritične sile izvijanja. Dobijena vrednost faktora proporcionalnosti za prvi ton oscilovanja iznosi $\lambda=3.99530 \cdot 10^{5}$, dok vrednost krtične sile izvijanja iznosi $311.60 \mathrm{kN}$.
The proportionality factor for the first tone oscillation $\lambda$ was applied in the Riks method to obtain the buckling force value. The obtained value of the proportionality factor for the first oscillation tone is $\lambda=3.99530 \cdot 10^{5}$ while the value of buckling force is $311.60 \mathrm{kN}$. 


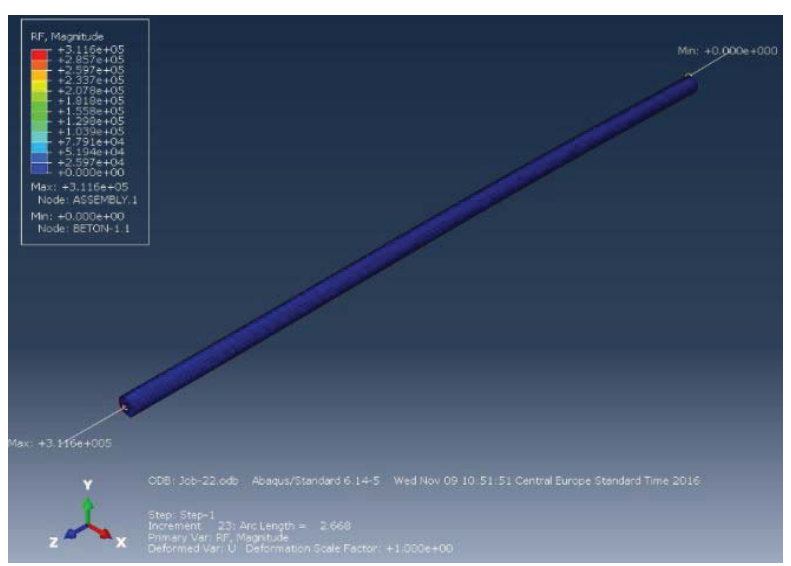

Slika 12: Rezultati proračuna za uzorak C1-vrednost kritične sile izvijanja Figure 12: Calculation results for the sample C1-value of the buckling force

$\mathrm{S}$ porastom odnosa D/t od $101.6 \mathrm{~mm} / 2.7 \mathrm{~mm}$ do $114.3 \mathrm{~mm} / 4.0 \mathrm{~mm}$ kritična sila se povećala 1.928 puta. $\mathrm{Na}$ slici 13 prikazana je zavisnost kritične sile izvijanja $\mathrm{P}_{\mathrm{cr}} \mathrm{S}$ porastom odnosa $\mathrm{D} / \mathrm{t}$.
By increasing D/t ratio from $101.6 \mathrm{~mm} / 2.7 \mathrm{~mm}$ to $114.3 \mathrm{~mm} / 4.0 \mathrm{~mm}$, a buckling force has increased 1.928 times. Figure 13 shows the dependence of the buckling force $\mathrm{P}_{\mathrm{cr}}$ with increasing $\mathrm{D} / \mathrm{t}$ ratio.

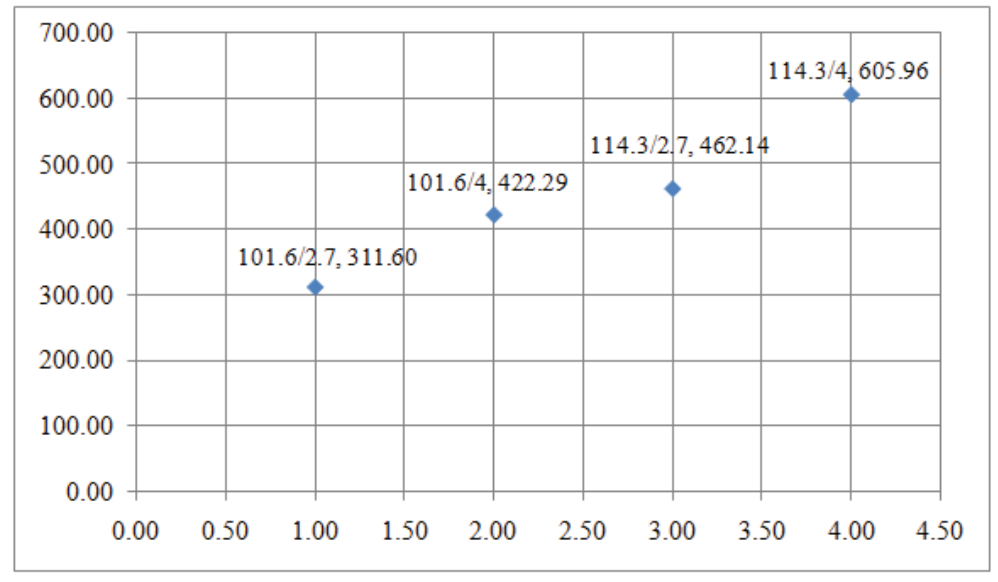

Slika 13: Zavisnost kritične sile izvijanja $P_{c r} s$ porastom odnosa $D / t$

Figure 13: Dependence of the buckling force $P_{c r}$ with increasing D/t ratio

- Uticaj graničnih uslova oslanjanja na vrednost kritične sile izvijanja Pcr:

Analizirana su dva slučaja graničnih uslova oslanjanja na donjem i gornjem kraju CFT stuba: uklještenje i zglavkast oslonac. Treba naglasiti da je za sve obostrano uklještene CFT stubove navedenih odnosa D/t došlo do gubitka aksijalne nosivosti pre gubitka stabilnosti stubova, te ovi rezultati nisu analizirani. Klasa betona je C25/30, dok je kvalitet čelika S355. U tabeli 1 . upoređene su dobijene vrednosti kritične sile izvijanja primenom računarskog programa ABAQUS s vrednostima kritičnih sila izvijanja sračunatih primenom EC4 [10].
- The influence of boundary conditions relying on the critical buckling force $P_{c r}$ :

Two cases of the boundary conditions of support at the lower and upper ends of the CFT column were analyzed: fixed and free supported. It should be emphasized that for all CFT columns fixed at both ends of the mentioned $D / t$ ratios there was a loss of axial load capacity before the stability of the columns was lost, and these results were not analyzed. The concrete class is C25/30, while the steel class is S355. Table 1 compares the obtained values of the buckling force using the ABAQUS computer program with the values of the buckling force calculated using EC4 [10]. 
Tabela 1. Vrednosti kritičnih sila izvijanja

Table 1. Values of buckling force

\begin{tabular}{|c|c|c|c|c|}
\hline $\mathrm{D} / \mathrm{t}$ & $101.6 / 2.7$ & $101.6 / 4.0$ & $114.3 / 2.7$ & $114.3 / 4.0$ \\
\hline $\begin{array}{c}\mathrm{N}_{\mathrm{Cr}, \mathrm{ABAQUS}} / \mathrm{N}_{\mathrm{EC} 4} \\
\text { Uklješten donji kraj CFT } \\
\text { stuba i zglavkasto } \\
\text { oslonjen gornji kraj CFT } \\
\text { stuba } \\
\text { Fixed lower end and free } \\
\text { supported upper end of } \\
\text { the CFT column }\end{array}$ & $311.60 / 319.18=0.976$ & $422.29 / 415.23=1.017$ & $462.14 / 473.94=0.975$ & $605.96 / 613.94=0.987$ \\
\hline $\begin{array}{l}\qquad \mathrm{N}_{\mathrm{cr}, \mathrm{ABAQUS}} / \mathrm{N}_{\mathrm{EC} 4} \\
\text { Zglavkasto oslonjen donji } \\
\text { i gornji kraj CFT stuba } \\
\text { Free supported lower and } \\
\text { upper ends of the CFT } \\
\text { column }\end{array}$ & $162.70 / 150.40=1.040$ & $212.21 / 203.46=1.043$ & $230.14 / 232.23=0.991$ & $307.15 / 300.83=1.021$ \\
\hline
\end{tabular}

\section{VERIFIKACIJA REZULTATA}

Kako bi se verifikovali rezultati, izvršena je komparacija rezultata eksperimentalnih ispitivanja $s$ rezultatima primenom važećih pravilnika (EC4, $\mathrm{ACl}, \mathrm{AS}$, AISC), kao i primenom računarskog programa ABAQUS. U tabelama 2, 3, 4 i 5 prikazani su rezultati proračuna kritične sile izvijanja za uzorke C1, C2, C3 i C4 sračunate primenom važećih pravilnika: EC4 po teoriji I reda, EC4 po teoriji II reda, $\mathrm{ACl}, \mathrm{AS}, \mathrm{AICS}$. Ove vrednosti upoređene su s vrednostima kritičnih sila izvijanja CFT stubova, dobijenim eksperimentalnim ispitivanjima.

\section{VERIFICATION OF RESULTS}

In order to verify the results, a comparison of the results of the experimental tests with the results of the application of the current regulations (EC4, $\mathrm{ACl}, \mathrm{AS}$, AISC) and the application of the ABAQUS computer program was made. Tables 2, 3, 4, and 5 show the results of the calculation of the buckling force for the samples C1, C2, C3 and C4 calculated using the current regulations: EC4 according to the first order theory, EC4 according to the second order theory, ACI, AS, AICS. These values are compared with the values of the buckling forces of CFT columns obtained by experimental tests.

Tabela 2. Kritična sila izvijanja CFT stuba za uzorak C1

Table 2. Buckling force of CFT column for sample C1

\begin{tabular}{|c|c|c|c|c|}
\hline $\mathrm{N}_{\text {TEST }}[\mathrm{kN}]$ & $\mathrm{N}_{\text {TEST }} / \mathrm{N}_{\text {EC4,1 }}$ & $\mathrm{N}_{\text {TEST }} / \mathrm{N}_{\text {EC4,II }}$ & $\mathrm{N}_{\text {TEST }} / \mathrm{N}_{\text {ACI/AS }}$ & $\mathrm{N}_{\text {TEST }} / \mathrm{N}_{\text {AISC }}$ \\
\hline 327.7 & 0.879 & 1.023 & 1.074 & 1.318 \\
\hline
\end{tabular}

Tabela 3. Kritična sila izvijanja CFT stuba za uzorak C2

Table 3. Buckling force of CFT column for sample C2

\begin{tabular}{|c|c|c|c|c|}
\hline $\mathrm{N}_{\text {TEST }}[\mathrm{kN}]$ & $\mathrm{N}_{\text {TEST }} / \mathrm{N}_{\text {EC4, I }}$ & $\mathrm{N}_{\text {TEST }} / \mathrm{N}_{\text {EC } 4, \mathrm{II}}$ & $\mathrm{N}_{\text {TEST }} / \mathrm{N}_{\text {ACI/AS }}$ & $\mathrm{N}_{\text {TEST }} / \mathrm{N}_{\text {AISC }}$ \\
\hline 489.1 & 0.879 & 1.028 & 1.098 & 1.194 \\
\hline
\end{tabular}

Tabela 4. Kritična sila izvijanja CFT stuba za uzorak C3

Table 4. Buckling force of CFT column for sample C3

\begin{tabular}{|c|c|c|c|c|}
\hline $\mathrm{N}_{\text {TEST }}[\mathrm{kN}]$ & $\mathrm{N}_{\mathrm{TEST}} / \mathrm{N}_{\mathrm{EC} 4, \mathrm{I}}$ & $\mathrm{N}_{\mathrm{TEST}} / \mathrm{N}_{\mathrm{EC} 4, \mathrm{II}}$ & $\mathrm{N}_{\mathrm{TEST}} / \mathrm{N}_{\mathrm{ACl} / \mathrm{AS}}$ & $\mathrm{N}_{\text {TEST }} / \mathrm{N}_{\mathrm{AISC}}$ \\
\hline 226.0 & 0.966 & 1.108 & 1.106 & 0.988 \\
\hline
\end{tabular}

Tabela 5. Kritična sila izvijanja CFT stuba za uzorak C4

Table 5. Buckling force of CFT column for sample C4

\begin{tabular}{|c|c|c|c|c|}
\hline $\mathrm{N}_{\text {TEST }}[\mathrm{kN}]$ & $\mathrm{N}_{\text {TEST }} / \mathrm{N}_{\mathrm{EC} 4,1}$ & $\mathrm{~N}_{\text {TEST }} / \mathrm{N}_{\mathrm{EC} 4, \mathrm{II}}$ & $\mathrm{N}_{\mathrm{TEST}} / \mathrm{N}_{\mathrm{ACI} / \mathrm{AS}}$ & $\mathrm{N}_{\mathrm{TEST}} / \mathrm{N}_{\text {AISC }}$ \\
\hline 319.0 & 0.918 & 1.058 & 1.070 & 0.955 \\
\hline
\end{tabular}


Na osnovu dobijenih rezultata, može se zaključiti da pravilnik EC4 daje najpribližnije rezultate s rezultatima eksperimentalnih ispitivanja, pri čemu je efektivna krutost na savijanje sračunata po teoriji drugog reda [10]. S druge strane, ukoliko se prema EC4 efektivna krutost na savijanje računa po teoriji prvog reda, dobijaju se vrednosti kritičnih sila izvijanja koje nisu na strani sigurnosti. Takođe, primenom pravilnika AISC, za uzorke C3 i C4 dobijaju se vrednosti kritičnih sila izvijanja stubova koje su vrlo bliske vrednostima dobijenim eksperimentalnim ispitivanjem, ali takođe nisu na strani sigurnosti.

S ciljem da se verifikuju predloženi numerički modeli, izvršena je komparacija rezultata eksperimentalnih ispitivanja $\mathrm{s}$ rezultatima primenom MKE, odnosno računarskog programa ABAQUS. Na slikama 14, 15, 16 i 17 prikazani su dijagrami zavisnosti kritične sile izvijanja $P_{c r}$ i inženjerske dilatacije $\Delta \mathrm{L} / \mathrm{L}$ za uzorke $C 1$ i C2 koji su $s$ donje strane uklješteni, a s gornje strane zglavkasto oslonjeni, kao i za uzorke C3 i C4 koji su i s donje i s gornje strane zglavkasto oslonjeni. Za sve ispitane uzorke, kritične sile izvijanja dobijene eksperimentalnim ispitivanjima veće su od kritičnih sila izvijanja dobijenih primenom računarskog programa ABAQUS. Međutim, ove razlike nalaze se u granicama od $3 \%$ do $7 \%$, pa se može zaključiti da se predloženi modeli dobro poklapaju sa ispitanim uzorcima.

Za uzorak $C 1$ (sl. 14), dijagram $\mathrm{P}_{\mathrm{cr}}-\Delta \mathrm{L} / \mathrm{L}$ dobijen primenom programa ABAQUS približno je linearan. To znači da se izvijanje desilo u elastičnoj oblasti. S druge strane, rezultati eksperimentalnih ispitivanja pokazuju da se javlja i nelinearno ponašanje CFT stuba. Ova pojava se može objasniti činjenicom da je uzorak $C 1$ u stanju da prihvati nešto veće opterećenje od prethodno sračunate vrednosti primenom računarskog programa ABAQUS (za oko 5\%), ali da je pri takvom intenzitetu opterećenja $u$ ivičnim vlaknima ostvaren napon na granici tečenja $f_{y}$.
On the basis of the obtained results, it can be concluded that the EC4 gives the most favourable results with the results of the experimental tests, with the effective bending rigidity calculated according to the second-order theory [10]. On the other hand, if according to EC4 effective bending rigidity is calculated according to the first-order theory, the values of critical forces are not on the safety side. Also, by applying the AISC rule, for the samples $\mathrm{C} 3$ and $\mathrm{C4}$, the buckling force values are obtained which are very close to the experimental test values but are also not on the safety side. In order to verify the proposed numerical models, a comparison of the results of experimental tests with the results of the application of FEM, i.e. the computer program ABAQUS, was made. Figures $14,15,16$, and 17 show the dependence of the buckling force $\mathrm{P}_{\mathrm{cr}}$ on the diagram and engineering strain $\Delta \mathrm{L} / \mathrm{L}$ for the $C 1$ and $C 2$ samples that are fixed at the bottom, and on the upper side are free supported, as well as for the samples C3 and C4, which are also free supported from the lower and upper sides. Buckling forces obtained by the experimental tests are greater than the forces obtained by applying the ABAQUS computer program for all tested samples. However, these differences are within the range of $3 \%$ to $7 \%$, so it can be concluded that the proposed models fit well with the tested samples.

For sample C1 (Figure 14), the diagram $\mathrm{P}_{\mathrm{cr}}-\Delta \mathrm{L} / \mathrm{L}$ obtained using the ABAQUS program is approximately linear. This means that the buckling has occurred in an elastic region. On the other hand, the results of experimental tests show that non-linear behaviour of the CFT column occurs. This phenomenon can be explained by the fact that the $C 1$ sample is able to accept a slightly higher load from the previously calculated value using the ABAQUS computer program (by about 5\%), but with that intensity of load the yield strength of steel $f_{y}$ in edge fibres is reached.

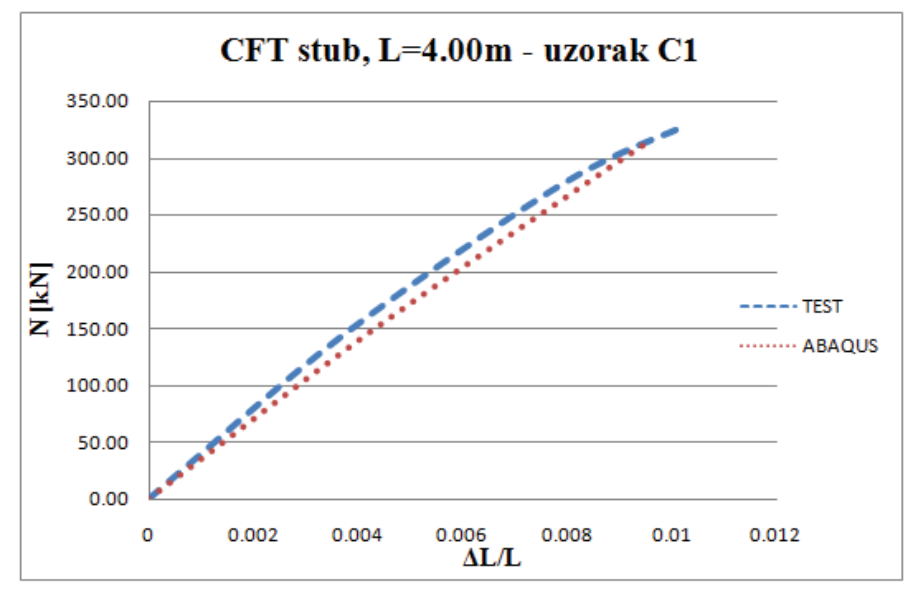

Slika 14: Komparacija dijagrama $\mathrm{P}_{\mathrm{cr}}-\Delta \mathrm{L} / \mathrm{L}$ za uzorak C1 Figure 14: Comparison of the diagrams $P_{c r}-\Delta L / L$ for sample $C 1$

Za uzorak C2 (sl. 15), dijagram $P_{c r}-\Delta L / L$ dobijen primenom programa ABAQUS takođe je približno linearan. Tek pri poslednjem inkrementu opterećenja u ivičnim vlaknima ostvaren je napon na granici tečenja $f_{y}$ u iznosu od $355 \mathrm{MPa}$, prikazan na slici 16.
For sample C2 (Figure 15), the diagram $P_{c r}-\Delta L / L$ obtained using the ABAQUS program is also approximately linear. Only at the last increment of the load in the edges of the fibres was the yield strength of steel $\mathrm{f}_{\mathrm{y}}$ of $355 \mathrm{MPa}$, shown in Figure 16. 


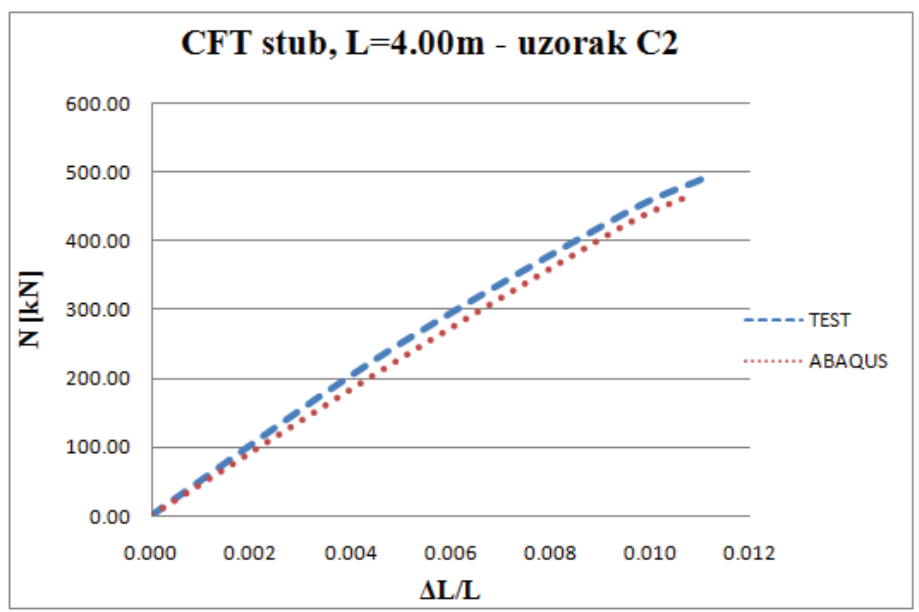

Slika 15: Komparacija dijagrama $\mathrm{P}_{\mathrm{cr}}-\Delta \mathrm{L} / \mathrm{L}$ za uzorak C2

Figure 15: Comparison of the diagrams $P_{c r}-\Delta L / L$ for sample $C 2$

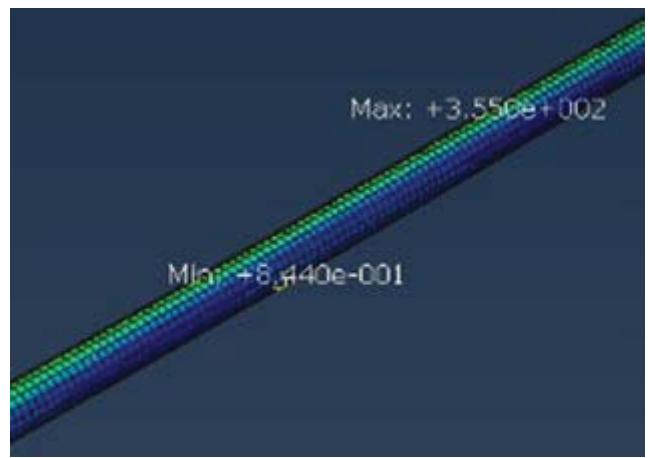

Slika 16: Vrednost napona u čeličnom profilu u poslednjem inkrementu opterećenja Figure 16: The value of the stress in the steel tube in the last load increment

Za uzorak C1 odnos vrednosti kritičnih sila izvijanja dobijenih eksperimentalnim ispitivanjima i primenom programa ABAQUS iznosi 1.048, dok je za uzorak C2 ovaj odnos jednak 1.051.
For the $C 1$ sample, the ratio of the buckling force values obtained by the experimental tests and the application of the ABAQUS program is 1.048 , while for the $C 2$ sample this ratio is 1.051 .

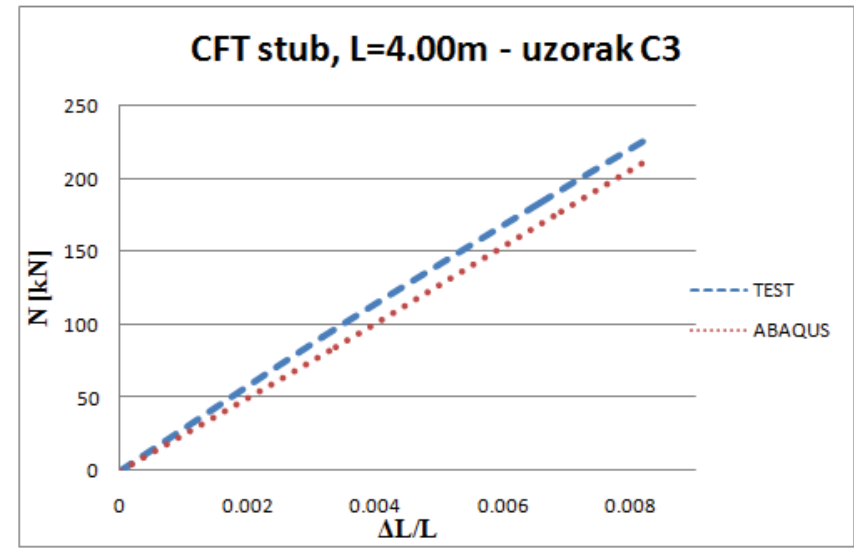

Slika 17: Komparacija dijagrama $\mathrm{P}_{\mathrm{cr}}-\Delta \mathrm{L} / \mathrm{L}$ za uzorak C3 Figure 17: Comparison of the diagrams $P_{c r}-\Delta L / L$ for sample $C 3$ 
Za uzorke C3 i C4 dijagrami $P_{c r}-4 L / L$ dobijeni eksperimentalnim ispitivanjima, kao i primenom programa ABAQUS jesu linearni. Za uzorak C3 odnos vrednosti kritičnih sila izvijanja dobijenih eksperimentalnim ispitivanjima i primenom programa ABAQUS iznosi 1.062 (sl. 17), dok je za uzorak C6 ovaj odnos jednak 1.036 (sl. 18).
For samples $C 3$ and $C 4$, the diagrams $P_{c r}-\Delta L / L$ obtained by experimental tests, as well as the application of the ABAQUS program, are linear. For sample $C 3$, the ratio of the buckling force values obtained by experimental tests and the application of the ABAQUS program is 1.062 (Figure 17), while for sample $C 4$ this ratio equals 1.036 (Figure 18).

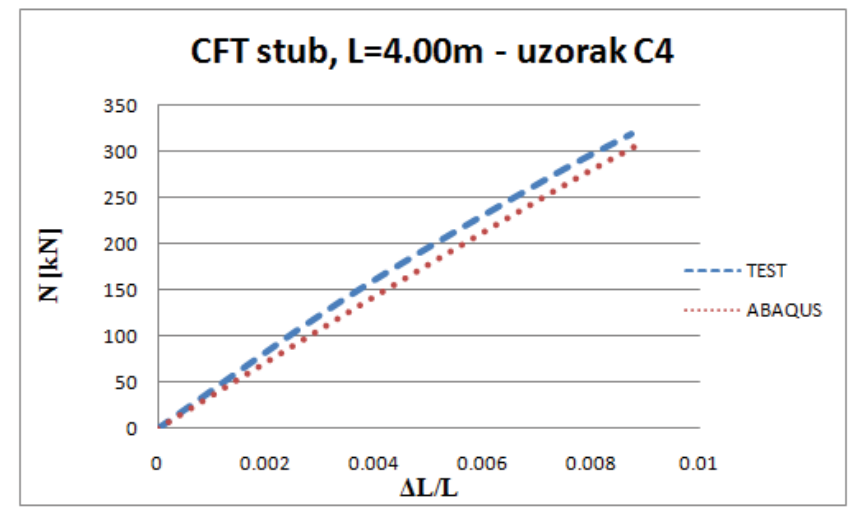

Slika 18: Komparacija dijagrama $\mathrm{P}_{\mathrm{cr}}-\Delta \mathrm{L} / \mathrm{L}$ za uzorak C4 Figure 18: Comparison of the diagrams $P_{c r}-\Delta L / L$ for sample $C 4$

\section{ZAKLJUČAK}

$\mathrm{U}$ radu su detaljno prikazana sopstvena eksperimentalna ispitivanja i modelske analize aksijalno pritisnutih umereno vitkih i vitkih kružnih CFT.

Primenom Riks-ove metode dostupne u računarskom programu ABAQUS uspešno se može modelirati nosivost umereno vitkih i vitkih CFT kružnih stubova. Na tačnost proračuna nosivosti CFT stubova značajan uticaj imaju usvojeni konstitutivni modeli za betonsko jezgro, čelični šuplji profil, kao i veza ovih elemenata. U radu je analiziran uticaj graničnih uslova oslanjanja, kao i uticaj odnosa D/t na vrednost kritične sile izvijanja.

$\mathrm{Na}$ osnovu rezultata eksperimentalnih ispitivanja izvršena je verifikacija rezultata proračuna prema važećim pravilnicima (EC4, ACl, AS, AISC) i korišćenjem numeričkog programa koji se zasniva na MKE (ABAQUS). Na osnovu dobijenih rezultata mogu se izvesti sledeći zaključci:

- pravilnik EC4 daje najpribližnije rezultate s rezultatima dobijenim eksperimentalnim ispitivanjem, pri čemu je neophodno uzeti u obzir uticaje drugog reda;

- primenom računarskog programa ABAQUS i usvajanjem odgovarajućih nelinearnih konstitutivnih modela za beton i konstrukcioni čelik, zadavanjem geometrijske nelinearnosti i drugih parametara kao što su definisanje veze betonskog jezgra i čeličnog profila, uspešno se može modelirati nosivost i stabilnost CFT stubova s različitim uslovima oslanjanja.

\section{CONCLUSION}

The paper presents in details our own experimental tests and model analyzes of axial loading moderately slender and slender circular CFT columns.

Using the Riks method available in the ABAQUS computer program, the load capacity of moderately slender and slender CFT circular columns can be modelled. Constitutive models for the concrete core, the steel tube, as well as the connection of these elements have a significant influence on the accuracy of the calculation of the CFT columns load capacity. The paper analyzes the influence of the boundary conditions, as well as the influence of the ratio D/t on the value of the buckling force.

Based on the results of the experimental testing, the results of the calculation according to the current regulations (EC4, ACI, AS, AISC) and the numerical program based on FEM (ABAQUS) were verified. Based on the obtained results, the following conclusions can be made:

- the EC4 gives the most favourable results with the results obtained by experimental testing, where it is necessary to take into account the second order effects.

- using the ABAQUS computer program and adopting appropriate nonlinear constitutive models for concrete and structural steel, by setting geometric nonlinearities and other parameters such as defining the connection between the concrete core and the stee tube, the load capacity and stability of CFT columns with different support conditions can be successfully modelled. 


\section{Zahvalnost:}

Prvi autor zahvaljuje Ministarstvu nauke Republike Srbije za finansijsku podršku u okviru projekta TR III 42012.

\section{LITERATURA} REFERENCES

[1] Shanmugam N.E., Lakshmi B.: State of the art report on steel-concrete composite columns, Journal of Constructional Steel Research 57, 2001, str. 1041-1080.

[2] Giakoumelis G., Lam D.: Axial capacity of circular concrete-filled tube columns, Journal of Constructional Steel Research 60, 2004, str. 1049_ 1068.

[3] Moon J., Roeder C.W., Lehman D. E., Lee H. E.: Analytical Modeling of Bending of Circular Concrete-Filled Steel Tubes, Engineering Structures 42 (2012), str. 349-361.

[4] Hatzigeorgiou G.: Numerical model for the behavior and capacity of circular CFT columns, Part II: Verification and extension, Engineering Structures 30, 2008, str. 1579-1589.

[5] Tao Z., Wang Z.B., Yu Q.: Finite element modelling of concrete-filled steel stub columns under axial compression, Journal of Constructional Steel Research 89, 2013, str. 122-131.

[6] Sakino K., Nakahara H., Morino S., Nishiyama I.: Behavior of Centrally Loaded Concrete-Filled Steel-Tube Short Columns, Journal of structural engineering, 2004, str. 180-188.

[7] Hu H.T., Huang C.S., Chen Z.L.: Finite element analysis of CFT columns subjected to an axial compressive force and bending moment in combination, Journal of Constructional Steel Research 61, 2005, str. 1692-1712.

[8] Deretić-Stojanović B., Kostić S., Stošić S.: Proračun spregnutih stubova od čelika i betona, Građevinski materijali i konstrukcije, vol.54, br. 1, (2011), str. 62-79

[9] Kostić S., Stošić S., Deretić-Stojanović B.: Prilog proračuna spregnutih stubova od čelika i betona, Građevinski materijali i konstrukcije, vol.54, br. 2, (2011), str. 3-16

[10] Evrokod 4: EN 1994-1-1:2004 Proračun spregnutih konstrukcija od čelika $i$ betona, Beograd, februar 2006.

[11] ACl: Building code requirements for structural concrete and commentary $\mathrm{ACl} 318-08$, Farmington Hills, Ml; 2008.

[12] Australian Standards AS410: Steel structures, AS4100-1998, Sydney (Australia), Standards Australia, 1998.

[13] AISC: Specification for structural steel buildings, AISC, Chicago, IL. 2010.

[14] Ellobody E., Youngb B., Lam D.: Behaviour of normal and high strength concrete-filled compact steel tube circular stub columns, Journal of Constructional Steel Research 62, 2006, str. 706715.

\section{Acknowledgements}

The first author thanks the Ministry of Science and Technology of the Republic of Serbia for the financial support through the project TD III 42012.

[15] Hu H.T., Asce M., Huang C.S., Wu M.H., Wu Y.M.: Nonlinear Analysis of Axially Loaded ConcreteFilled Tube Columns With Confinement Effect, Journal of structural engineering, 2003, str. 13221329.

[16] Liang Q.Q.: High strength circular concrete-filled steel tubular slender beam-columns,Part l: Numerical analysis, Journal of Constructional Steel Research 67, 2011, str. 164-171.

[17] Liang Q.Q., Fragomeni S.: Nonlinear analysis of circular concrete-filled steel tubular short columns under axial loading, Journal of Constructional Steel Research 65, 2009, str. 2186-2196.

[18] Saenz L.P.: Discussion of Equation for the stressstrain curve of concrete by $P$. Desayi, and $S$. Krishnan, Journal of the American Concrete Institute 1964; 61, str. 1229-1235.

[19] Lee S.H., Uy B., Kim S.H., Choi Y.H., Choi S.M.: Behavior of high-strength circular concrete-filled steel tubular (CFST) column under eccentric loading, Journal of Constructional Steel Research 67, 2011, str. 1-13.

[20] Tang J., Hino S., Kuroda I., Ohta T.: Modeling of stress strain relationships for steel and concrete in concrete filled circular steel tubular columns, Steel Construction Engineering, JSSC 1996, 3(11), str. 35-46.

[21] Andrade de Oliveira W.L., Silvana De Nardin, H. de Cresce El Debsa A.L., Khalil El Debs M.: Influence of concrete strength and length/diameter on the axial capacity of CFT columns, Journal of Constructional Steel Research 65, 2009, str. 21032110.

[22] Liang Q.Q.: High strength circular concrete-filled steel tubular slender beam-columns, Part II: Fundamental behavior, Journal of Constructional Steel Research 67, 2011, str. 172-180.

[23] Dundu M.: Compressive strength of circular concrete filled steel tube columns, Thin-Walled Structures 56, 2012, str. 62-70.

[24] Chacón R., Mirambell E., Real E.: Strength and ductility of concrete-filled tubular piers of integral bridges, Engineering Structures 46, 2013, str. 234 246.

[25] ABAQUS standard user's manual version 6.12, 2012.

[26] Evrokod 2: EN 1992-1-1:2004 Proračun betonskih konstrukcija, deo 1-1: opšta pravila i pravila za zgrade, Beograd, februar 2006. 


\section{PRORAČUN NOSIVOSTI I STABILNOSTI UMERENO VITKIH I VITKIH CENTRIČNO PRITISNUTIH KRUŽNIH CFT STUBOVA}

Marija LAZOVIĆ

Biljana DERETIĆ-STOJANOVIĆ

Janko RADOVANOVIĆ

$\mathrm{U}$ radu su prikazani program i rezultati eksperimentalnog ispitivanja nosivosti i stabilnosti umereno vitkih i vitkih kružnih CFT stubova. Analiziran je uticaj odnosa prečnika i debljine zida čeličnog profila, kao i uticaj graničnih uslova oslanjanja na vrednost kritične sile izvijanja. Izvršena je i numerička simulacija ispitanih uzoraka primenom metode konačnih elemenata i računarskog programa ABAQUS. U modelu su zadati nelinearni konstitutivni modeli za beton jezgra i konstrukcioni čelik šupljeg profila, kao i veza ova dva elementa. Primenom modifikovane Riks-ove metode sračunata je kritična sila izvijanja CFT stuba. Verifikacija rezultata izvršena je upoređivanjem sopstvenih eksperimentalnih rezultata s važećim pravilnicima: EC4, $\mathrm{ACl}, \mathrm{AS}, \mathrm{AISC}$, kao i s rezultatima dobijenim primenom računarskog programa ABAQUS.

Ključne reči: centrično pritisnuti kružni CFT stubovi, nosivost i stabilnost, eksperimentalno ispitivanje, nelinearna analiza

\section{CALCULATION OF LOAD CAPACITY AND STABILITY OF MODERATELY SLENDER AND SLENDER AXIAL LOADED CIRCULAR CFT COLUMNS}

Marija LAZOVIC

Biljana DERETIC-STOJANOVIC

Janko RADOVANOVIC

In this paper, results of experimental investigation of bearing capcity and stability of slender and moderately slender CFT circural tubes are presented. The efects of ratio thickness/ radius of steel cross section and support conditions are investigated. Numerical simulation for the tested examples was performed in computer program ABAQUS. In this simulations, nonlinear constitutive models were used for modelling of concrete, steel and concrete/steel connection. With modified Rick's method critical buckling force for the CFT column was calculated. Verification of the obtained experimental results was performed with comparison with several world standards: EC4, ACI, AS, AISC, as well as with the results obtained in ABAQUS.

Key words: axial loaded circular CFT column, bearing capacity and stability, experimental testing, nonlinear analysis 